\title{
FUNGSI TOPENG TEMBUT-TEMBUT DESA SEBERAYA KECAMATAN TIGA PANAH KABUPATEN KARO
}

\author{
Sartika Br Sembiring ${ }^{1 *}$ dan Guntur ${ }^{2 *}$ \\ Program Pascasarjana, Minat Pengkajian Seni Rupa, \\ Institut Seni Indonesia Surakarta \\ Jl. Ki Hajar Dewantara, No. 19, Jebres, Kota Surakarta, 57126, \\ Jawa Tengah, Indonesia. \\ Email: sartikakembaren@gmail.com
}

\begin{abstract}
Abstrak
Penelitian mengenai fungsi topeng Tembut-Tembut Seberaya berkaitan dengan proses upacara ritual yang dilakukan di Desa Seberaya. Upacara Ritual tersebut merupakan budaya tradisi yang sudah berlangsung sejak kemunculan pertunjukan topeng ini. Pertunjukan yang dilakukan berhubungan dengan pemanggilan air hujan. Dalam ritual pemanggilan air hujan, dilakukan beberapa tahap prosesi oleh generasi penerus topeng. Prosesi yang dilaksanakan memiliki runtutan dalam tata pelaksanaannya. Ada tahapan yang harus dilaksanan oleh generasi penerus apabila topeng ini akan dipertontonkan untuk masyarakat luas. Penelitian ini bertujuan untuk mengetahui bagaimana fungsi tembut-tembut Desa Seberaya dalam budaya tradisi dan modern saat ini. Metode yang digunakan adalah kualitatif interpretatif dengan pendekatan teori Feldman. Fungsi suatu karya seni terdiri dari fungsi personal, fungsi sosial dan fungsi fisik. Hasil penelitian menunjukkan bahwa fungsi tembut-tembut mengalami pergeseran seiring perkembangan zaman. Nilai sakral pada tembut-tembut berkaitan dengan upacara ritual pemanggilan air hujan tetap masih ada, berbeda ketika tembut-tembut menjadi sebuah pertunjukkan dalam sebuah acara pertunjukkan. Fenomena yang ada pada masa sekarang adalah tembut-tembut digunakan sebagai sebuah acara pertunjukkan.
\end{abstract}

Kata Kunci: Topeng, Tembut-tembut, Ritual, dan Fungsi.

\begin{abstract}
Research on the function of the Tembut-Tembut Seberaya mask is related to the process of ritual ceremonies performed in Seberaya Village. The ritual ceremony is a traditional culture that has been going on since the appearance performed in Seberaya Village. The ritual ceremony is a traditional culture that has been going on since the appearance of this mask show. Performances related to rainwater calling. In the ritual of summoning rainwater, several stages procession are carried out by the next generation of masks. The procession carried out has a sequence in its implementation. There are stages that must be carried out by the next generation if this mask will be shown to the wider community. This study aims to find out how the function of Seberaya Village's pottery is in traditional and modern culture. The method used is interpretative qualitative with the Feldman theory approach. The function of an artwork consists of personal functions, social functions and physical functions. The results of the research show that the functions of the pottery experience a shift over time. The sacred value of the pots associated with the ritual ceremony of summoning rainwater still remains, different when the pottery becomes a performance in a performance event. The phenomenon that exists today is that pottery is used as a show.
\end{abstract}

Keywords: Mask, Shots, Rituals and Functions.

\section{PENDAHULUAN}

Keberadaan karya seni topeng tembut-tembut ini memiliki fungsi tertentu dalam kehidupam masyarakat suku Karo. Topeng tembut-tembut ini terdiri dari lima karakter yaitu 1) Karakter Panglima 2) Karakter Piherta Sembiring Depari 3) Karakter Nimaisa Sembiring Milala 4) Karakter Kikir Labang 5) Karakter Perik Gurda-Gurdi. Kehadiran topeng ini sebagai pusat kegiatan spriritual dan sakral bagi tradisi masyarakat Seberaya. Kegiatan spriritual dan sakral dalam masyarakat Karo akan terlihat ketika melakukan suatu prosesi upacara. Tembut-tembut ini merupakan salah satu budaya tradisi yang mencoba bertahan ditengah pro-kontra dalam masyarakat. Fenomena pro-kontra diakibatkan oleh pertentangan kepercayaan leluhur dengan keyakinan masyarakat yang telah memeluk agama. Dalam satu sisi masyarakat tetap percaya akan nilai magis yang terdapat pada topeng tembut-tembut, akan tetapi disisi lain masyarakat menilai jika nilai magis yang terdapat adalah kegiatan pemujaan terhadap berhala. 


\section{Gorga Jurnal Seni Rupa \\ Volume 07 Nomor 01 \\ p-ISSN: 2301-5942 | e-ISSN: 2580-2380}

Perkembangan tradisi tentang kepercayaan yang dianut oleh masyarakat Karo salah satunya seperti Desa Seberaya mengalami pergerasan dimana agama perbeg $u^{l}$ berubah nama menjadi pemena ${ }^{2}$. Perubahan ini terjadi karena adanya anggapan miring tentang agama perbegu yang menyembah kekuatan gaib. Agama pemena kemudian berkembang, sebagian besar penganutnya menjadi penganut agama Hindu Dharma. Pemena artinya kepercayaan terhadap roh leluhur nenek moyang mereka. Kepercayaan ini berlangsung sampai saat ini, dimana praktek-praktek tradisi tentang leluhur nenek moyang tetap terjaga walaupun sebagian besar sudah memeluk agama Islam dan Kristen.

Tujuan dari penelitian adalah mengetahui bagaimana fungsi topeng Tembut-tembut dalam budaya tradisi maupun budaya modern. Manfaat yang diperoleh adalah memberikan wawasan tentang ritual yang dilaksanakan dalam upacara pemanggilan air hujan berbeda dengan ritual untuk sebuah pertunjukkan perayaan hari besar misalnya pesta tahunan. Dengan penelitian ini memperkaya referensi tentang budaya pada topeng tembut-tembut yang berkaitan dengan proses ritual dalam masyarakat Karo.

Metode yang digunakan adalah kualitatif interpretatif dengan konsep pemikiran Feldman yakni adanya fungsi personal, sosial dan fisik dari suatu karya seni yang diciptakan oleh seorang seniman. Fungsi sebuah karya menurut Feldman akan terlihat dari beberaya kriteria yang dimiliki oleh karya tersebut. Karya tersebut akan menggambarkan fungsinya ketika sebuah karya dipakai sekaligus dilihat oleh suatu masyarakat. Fokus penelitian ini tentang fungsi topeng dalam kehidupan masyarakat Karo khususnya Desa Seberaya.

\section{METODE PENELITIAN}

\section{Upacara Tembut-Tembut Desa Seberaya Dalam Budaya Tradisi}

\section{Ritual Topeng Dalam Upacara Pemanggilan Air Hujan}

Prosesi upacara pemanggilan air hujan dilakukan melalui beberapa tahapan mulai dari topeng tersebut ipangiri $^{3}$ sampai selesai pertunjukkan dan topeng kembali masuk ke dalam rumah. Tahapan pertama yang dilakukan adalah erpangir. Erpengir berasal dari kata pangir yang berarti langir, erpangir artinya berlangir. Arti dalam pembasahan upacara ritual tradisi Karo, erpangir merupakan upacara religius berdasarkan kepercayaan pemena. Kegiatan ini dilakukan perseorangan atau sebuah keluarga maupun penduduk desa dengan cara mandi ke sungai dengan menyiapkan beberapa persyaratan agar kelak diberkati oleh sang Pecipta dan terhindar dari hal-hal kurang baik.

Topeng tembut-tembut kemudian dibersihkan dengan air campuran yang telah disiapkan. Dalam membersihkan topeng ini kumpulan bahan tersebut harus dikumpulan terlebih dahulu dan diracik oleh penerus topeng tembut-tembut. Ada tiga tahapan yang harus dilakukan ketika membersihkan tembut-tembut yaitu lau penguras, lau peniresen dan cimpa buka siang. Masing-masing tahapan memiliki bahan-bahan tersendiri yang prosesnya juga memiliki alur sendiri.

Tahapan pertama yang dilakukan adalah membersihkan dengan lau penguras. Lau penguras artinya air pembersih atau air untuk menyucikan topeng. Ketika bahan-bahan siap untuk digunakan, maka topeng akan dikeluarkan dari peti penyimpan. Topeng tembut-tembut akan diletakkan diruang tamu dengan menggunakan alas kain putih. Selain kain putih, topeng juga harus diletakkan diatas tikar yang berwarna putih. Tikar yang berwarna putih ini dianyam dari dauh nipah, dalam masyarakat karo penamaan untuk tikar ini adalah amak mentar. Dalam prosesi adat masyarakat Karo ketika ada pesta adat seperti perkawinan tikar putih ini digunakan untuk tamu yang paling dihormati. Pembersihan topeng pada tahap ini dilakukan ketika topeng masih berada didalam rumah. Ritual ini dilakukan dengan niat agar topeng benar-benar bersih atau benar-benar suci ketika digunakan untuk upacara pemanggilan air hujan.

Tahapan kedua yang dilakukan untuk pembersihan topeng adalah dengan menggunakan lau peniresen. Lau penirisen artinya air pembersihan tahap kedua setelah dilakukan pembersihan tahap awal. Topeng yang sudah diletakkan diatas kain dan tikar putih kemudian akan dibersihkan kembali dengan lau penirisen. Pembersihan topeng menggunakan air tahapan kedua ini bertujuan agar topeng yang sudah bersih dan suci siap dibawa keluar dari rumah. Pembersihan topeng dalam proses ini disebut sebagai penyucian keluar rumah. Sebelum keluar dari rumah, topeng harus melawati tahapan pembersihan kedua, artinya setiap tahap pembersihan topeng memiliki tujuan masingmasing dan tata pelaksanaan harus berurutan. Dalam proses ini ada beberapa bahan yang tidak bisa disebutkan ke masyarakat umum, sehingga bersadarkan wawancara dengan Dwikora Sembiring bahan yang 
yang disebutkan hanya sebagian, tidak seutuhnya karena ada hal-hal yang tidak bisa diketahui oleh orang lain. Proses ini dilakukan oleh generasi penerus topeng tidak bisa dilakukan oleh orang lain.

Tahapan ketiga dalam proses ritual tembut-tembut adalah menyajikan beberapa bahan makanan yang harus dilaksanakan. Proses penyajian beberapa bahan makanan disebut sebagai cimpa buka siang. Cimpa adalah makanan khas masyarakat Karo yang terbuat dari beras ketan dengan cara dikukus. Cimpa ini memiliki rasa yang manis karena berisi kelapa parut yang diberi gula merah dan dimasak secara bersamaan. Dahulu daun yang digunakan untuk pembuatan cimpa ini dalah daun singkut, namun karena daun tersebut sudah semakin jarang dijumpai, kemudian digantikan dengan daun pisang. Cimpa ini memiliki jenis-jenis tersendiri tergantung dari bahan dan cara pembuatannya. Adapun beberapa jenis makanan cimpa yaitu cimpa unung, cimpa matah, cimpa lepat, cimpa tuang, dll.

Melihat bagaimana masyarakat Karo khususnya Seberaya melakukan tradisi ritual tentang upacara pemanggilan air hujan, sejalan dengan pendapat Claire Holt praktek-praktek keagaman ataupun penyembahan ritual merupakan ajaran filosofis dan mistis yang sudah ada sejak dulu dan biasanya merupakan perantara antara manusia dan dunia roh-roh (Holt : 2000: 33). Menurut victor Turner ritual bisa mengungkapkan nilai pada tingkat terdalam seseorang, misalnya ekspresi pria dalam ritual kelompok masyarakat. Ritual bisa saja dilakukan oleh kelompok masyarakat tertentu yang memiliki isyarat untuk dilaksanakan. Di dalam proses tersebut, ada peran antar unit satu dengan lainnya membentuk sebuah ekspresi atau simbol tertentu yang merupakan gabungan unsur ritual itu sendiri (Turner: 1977: 6-15).

Menurut Koentjaraningrat pangkal religi dalam masyrakat tradisional adalah emosi atau getaran jiwa yang timbul kaena kekaguman terhadap hal-hal atau gejala tertentu yang sifatnya luas biasa. Kekuatan tersebut diluar akal logika manusia biasa sehingga sering disebut kekuatan supernatural. Selain kekuatan supernatural, manusia pada zaman dahulu juga percaya kepada kekuatan anggota tubuh manusia, hewan ataupun tumbuhan yang memiliki kekuatan gaib. Kekuatan gaib yang dipercaya menjadikan manusia berhati-hati bila berhubungan dengan hal-hal tersebut. Karena masyarakat percaya disamping ada kegunaan dari sesuatu yang mereka yakini, juga bisa menimbulkan bahaya gaib(Koentrajaningrat: 2007: 61$63)$.
Topeng Tembut-Tembut Desa Seberaya Dalam Budaya Modern

\section{Ritual Topeng Tembut-Tembut Dalam Perayaan Acara Hari Besar}

Ritual secara umum dipandang oleh masyarakat sebagai fenomena sosial yang secara implisit atau eksplisit memiliki kaitan dengan kondisi psikologis tertentu. Kondisi psikologis ini berhubungan dengan tolak ukur suatu budaya masyarakat. Masyarakat satu dengan masyarakat lain, akan memiliki fenomena ritual tersendiri tentang sebuah karya seni leluhur yang terlahir di zamannya. Ketika sebuah ritual lahir di zaman dahulu dikaitkan dengan peristiwa yang memiliki unsur sakral. Menurut Eliade dunia (yaitu dunia kita) adalah semesta yang didalamnya yang sakral memanifestasikan diri (Eliade:2002:24).

Topeng tembut-tembut tidak memiliki ritual khusus seperi ketika digunakan untuk ritual pemanggilan air hujan. Jika ada hanya sebatas membersihkan topeng tetapi tidak melewati beberapa rangkaian seperi ritual dalam budaya tradisi. Tata cara pelaksanaan ritual topeng yang berkaitan dengan budaya modern adalah topeng tetap melewati proses pembersihan erpangir. Proses pembersihan yang dilakukan tidak seperti tahapan-tahapan yang sudah dijelaskan pada pembahasan sebelumnya. Topeng setelah dibersihkan akan tetap dikeluarkan dari dalam peti penyimpanan. Setelah dikeluarkan topeng juga diletakkan di atas tikar putih dan kain putih seperti penjelasan sebelumnya. Setelah topeng siap dibersihkan, maka topeng sudah bisa keluar rumah untuk dipentaskan.Topeng akan dikenakan oleh masing-masing penari laki-laki, tidak ada perempuan yang menarikan topeng tembut-tembut. Untuk menarikan topeng hanya kerabat dekat yang bisa melakukannya, penari selalu berasal dari pihak anak beru dari keluarga Dwikora Sembiring.

\section{HASIL DAN PEMBAHASAN}

Pada pembasahan sebelumnya sudah dipaparkan bagaimana keterkaitan ritual dengan proses pertunjukkan yang ada di dalam topeng tembut-tembut. Proses ritual sangat berperan penting ketika berhubungan dengan upacar pemanggilan air hujan. Setelah keterkaitan kedua hubungan tersebut dijelaskan maka kemudian yang harus diperhatikan adalah tentang fungsi topeng tembut-tembut didalam masyarakat itu sendiri.

Dalam sebuah karya seni, fungsi merupakan salah satu peran yang sangat penting. Fungsi sebuah karya seni akan terlihat dari ide gagasan sang seniman. Seniman biasanya memiliki maksud tertentu dalam menciptakan sebuah karya. Secara umum dalam budaya nusantara, 


\section{Gorga Jurnal Seni Rupa \\ Volume 07 Nomor 01 \\ p-ISSN: 2301-5942 | e-ISSN: 2580-2380}

karya seni topeng tidak bisa dipisahkan dengan sebuah pertunjukkan tari.

Pembahasan tentang fungsi topeng tembut-tembut akan dianalisis menggunakan pendekatan Feldman. Menurut Feldman sebuah karya seni memiliki tiga fungsi yaitu fungsi personal, fungsi fisik dan fungsi sosial.

\section{Fungsi Personal Tembut-Tembut Desa Seberaya}

Menurut feldman sebuah karya seni dapat dikatakan bisa bersifat personal apabila karya yang dibuat sebuah seniman bisa mengkomunikasikan perasaan-perasaan ataupun ide. Karya seni yang diciptakan memiliki hubungan dengan emosi-emosi pribadi tentang kehidupan ataupun sebuah peristiwa yang akrab dengan masyarakat. Adapun kriteria sebuah karya seni yang bersifat personal yaitu memiliki beberapa sifat seperti ini: Seni dan Ekpresi Psikologis, cinta, seks, perkawinan, ekspresi tentang hubungan spritual dan ekspresi estetis.

Topeng tembut-tembut dikategorikan memiliki beberapa kriteria karya yang bersifat personal. Fungsi personal yang ada didalam topeng tembut-tembut adalah topeng diciptakan sebagai bentuk ekspresi Pirei Sembiring Depari tentang topeng yang jika dilihat memiliki ciri khas tersendiri yang berbeda dengan karya pengrajin Joker Barus, ciri yang membedakan kedua hasil karya seniman tersebut adalah tampak pada dagu topeng, kumis serta gigi topeng. Fungsi personal seperti ini masuk kedalam kategori ekspresi psikologis seorang seniman dalam menciptakan karya.

Topeng memiliki fungsi yang berkaitan dengan cinta dan perkawinan. Hal tersebut bisa dilihat dari ide gagasan penciptaan topeng tembut-tembut yang berkaitan dengan cinta seorang pemuda kepada seorang gadis yang memiliki merga sama. Fungsi topeng ini sebagai peringatan perkawinan sesama klan merga Sembiring Depari dengan Sembiring Milala. Fungsi personal topeng masuk dalam kategori cinta dan perkawinan Piherta Sembiring Depari dengan Nimaisa Sembiring Milala.

Topeng diciptakan berkaitan dengan hubungan spiritual religi masyarakat terhadap Tuhan tentang kepercayaan meminta doa agar diturunkan hujan melalui tembut-tembut dalam upacara ritual pemanggilan air hujan. Fungsi topeng dalam hubungan spiritual manusia dengan Tuhannya termasuk kategori fungsi personal hubungan spiritual.

Kategori fungsi personal topeng tembut-tembut tentang ekspresi estetis adalah terlihat topeng dibuat sedemikian rupa indahnya menurut pandangan masyarakat Karo misalnya tentang penggunaan warna yang digunakan dalam topeng. Penggunaan warna dalam topeng terlihat hanya tidak lebih dari lima warna yang digunakan yaitu hitam, putih, merah, kuning dan hijau. Penggunakan warna pada topeng disesuaikan dengan budaya masyarakat Karo.

Selain kriteria diatas ada beberapa hal yang ditemukan peneliti ketika dilapangan tentang fungsi personal tembut-tembut yaitu topeng hanya dimainkan oleh pihak keluarga saja. Penari topeng berasal dari dalam keluarga Sembiring Depari, tidak dibenarkan jika penari dilakukan diluar keluarga inti. Selain hal tersebut, apabila ada anggota keluarga yang menginginkan pertunjukkan topeng ketika hendak melakukan pesta pernikahan, maka topeng akan dikeluarkan dan akan dipertunjukkan pada pesta pernikahan keluarga.

\section{Fungsi Sosial Tembut-Tembut Desa Seberaya}

Sebuah karya seni umumnya menunjukkan suatu fungsi sosial ketika karya tersebut diciptakan bagi seorang penonton. Seorang seniman yang menciptakan karya seni, selain berdasarkan keinginan sendiri, ia memiliki harapan tentang karya yang dihasilkan akan mendapat tanggapan dari masyarakat. Tanggapan yang diharapkan berupa pujian ataupun sambutan baik tentang karya yang sudah dihasilkan.

Menurut Feldman karya seni itu menunjukkan suatu fungsi sosial apabila:

a.ia (karya seni itu) mencari atau cenderung memperngaruhi perilaku kolektif orang banyak.

b.Karya itu diciptakan untuk dilihat atau dipakai (dipergunakan), khususnya di dalam situasi-situasi umum.

c.Karya seni itu mengekspresikan atau menjelaskan aspek-aspek tentang eksistensi sosial atau kolektif sebagai lawan dari bermacam-macam pengalaman personal maupun individual.

Sebuah karya seni selalu di usahakan untuk mempengaruhi perilaku sosial suatu masyarakat yang tergabung dalam tatanan sistem sosial. Karya seni memiliki peran dalam mengatur cara berpikir bahkan mempengaruhi perasaan masyarakat dalam bermacam fenomena yang dihadapi masyarakat sehari-hari. Fenomena fungsi sosial karya seni bisa dilihat dari bagaimana karya tersebut berhadapan dengan situasi tertentu misalnya: 


\section{Gorga Jurnal Seni Rupa \\ Volume 07 Nomor 01 \\ p-ISSN: 2301-5942 | e-ISSN: 2580-2380}

\section{Ekspresi Politik dan Ideologi}

Dalam fenomena situasi ini, topeng tembut-tembut dipertontonkan dengan tujuan topeng tidak hanya eksis untuk menghibur dan memuaskan perasaan yang melihatnya. Eksistensi topeng lebih mengedepankan agar masyarakat tetap mengingat keberdaan topeng sebagai suatu tradisi leluhur. Dalam hal ini ada hubungan fungsi topeng dalam politik yang berhubungan dengan ekonomi. Penciptaan karya topeng yang dilakukan oleh pengrajin memiliki konteks ekonomi. Fenomena ini terlihat, ketika topeng diproduksi menjadi komoditi pasar dan diperjualbelikan oleh pembeli yang memesan kepada pengrajin Joker Barus. Topeng yang dihasilkan pengrajin di fungsikan untuk koleksi pribadi sebagai hiasan dirumah, koleksi museum dan sebagian digunakan untuk kebutuhan pariwisata serta keperluan pementasan sebuah sanggar.

\section{Ekspresi Diskripsi Sosial}

Maksud sebuah karya seni dalam situasi ekspresi diskripsi sosial adalah karya seni yang sederhana mampu menguraikan sendi-sendi kehidupan. Adanya penemuan nilai yang dapat membantu masyarakat mengoreksi, membandingkan dan meningkatkan kualitas kehidupan sosial masyarakat. Fungsi topeng dalam situasi seperti ini bisa dilihat dari pertunjukkan tembut-tembut yang bertujuan untuk memperlihatkan kembali kepercayaan tradisi leluhur yang wajib dilestarikan. Topeng tembut-tembut memberikan pengaruh dalam mengoreksi pandangan masyarakat, bahwa tembut-tembut bukanlah benda yang dipuja, melainkan sebuah karya leluhur yang memiliki cerita tersendiri dalam proses penciptaannya.

\section{Alat Pujian dan Perayaan}

Fungsi topeng tembut-tembut dalam situasi sebuah perayaan digunakan sebagai upacara ritual pemanggilan air hujan yang memiliki tahapan-tahapan khusus. Dalam ritual pemanggilan air hujan fungsi topeng sebagai alat penghubung antara manusia dengan sang Pencipta. Seiring perkembangan zaman, tembuttembut Seberaya mengalami pergeseran fungsi. Topeng juga difungsikan dalam beberapa perayaan, misalnya peringatan Hari Kemerdekaan Indonesia, pesta tahunan, guro-guro aron, maupun penyambutan kepala daerah.

\section{Sindiran}

Dalam situasi sosial masyarakat Karo, topeng tembuttembut lebih mengarah kepada suatu nasehat yang baik. Topeng tembut-tembut tidak digunakan untuk situasi berupa sindiran, melainkan difungsikan sebagai sebuah nasehat agar tidak melakukan pernikahan sesama merga. Nasehat tersebut lebih masuk kedalam kategori sebagai peringatan kepada masyarakat Karo.

Topeng tembut-tembut Seberaya bisa dikategorikan memiliki fungsi sosial sesuai pemaparan Feldman tentang fungsi sosial sebuah karya seni berdasarkan kriteria maupun situasi-situasi tertentu seperti pembahasan di atas. Namun, di lain sisi kita harus melihat topeng tembut-tembut mempengaruhi sikap masyarakat Karo khususnya Seberaya. Pengaruh nyata yang terlihat menunjukkan walaupun masyarakat modern telah memeluk keyakinan agama, akan tetapi mereka tetap percaya kepada kekuatan magis yang terdapat dalam topeng. Selalu ada pro-kontra dalam setiap pertunjukkan topeng tembut-tembut. Namun Dwikora berusaha menunjukkan eksistensi pertunjukkan topeng ini ditengah pro-kontra upacara ritual dengan agama yang dianut oleh masyarakat Karo. Fenomena pro-kontra yang terjadi berkaitan dengan pertentangan kepercayan lama yang sebagian masih dianut oleh masyarakat Karo dengan masyarakat yang sudah memeluk agama Kristen dan Islam.

\section{Fungsi Fisik Tembut-Tembut Desa Seberaya}

Sebuah karya memiliki fungsi fisik yang dimaksud oleh Feldman adalah suatu ciptaan objek-objek yang dapat berfungsi sebagai wadah atau alat. Kedua hal tersebut dipergunakan sekaligus juga dilihat. Objek sebagai wadah dan alat, keduanya perlu didesain sebaikbaiknya agar dapat berfungsi secara efisien. Satu aspek dari fungsi-fungsi mereka adalah penampilan visual objek itu sendiri.

Melihat pemaparan Feldman, bahwa topeng tembuttembut Seberaya memiliki fungsi fisik. Fungsi fisik yang terlihat adalah topeng difungsikan sebagai wadah penutup seluruh kepala dan wajah seorang penari dalam pertunjukkan. Topeng tembut-tembut sengaja didesain ukurannya yang melebihi ukuran normal kepala manusia sehingga ketika menggunakannya, berfungsi sangat efisien dalam memakai ketika pertunjukkan. Karya seperti tembut-tembut terlihat efisien ketika orang-orang dengan mudah menggunakannya dan kelihatan baik ketika sebagian orang dapat membeli karya tersebut dengan harga yang mahal.

Tembut-tembut juga digunakan sebagai alat pertunjukan untuk mendatangkan hujan. Topeng dikatakan sebagai alat karena menurut Feldman fungsi fisik seni dihubungkan penggunaan benda-benda yang efektif sesuai kriteria kegunaan dan efisiensi, baik penampilannya maupun tuntutannya (permintannya). Dalam pertunjukkan tembut-tembut, terlihat adanya 


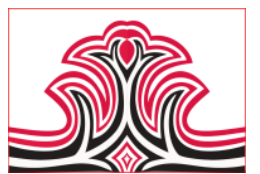

tuntutan topeng untuk memangil hujan pada musim kemarau. Selain fungsi tersebut, topeng juga digunakan sebagai tolak bala terhadap niat-niat jahat kepada orang maupun Desa Seberaya sendiri

Adapun visual dari setiap karakter topeng tembuttembut Desa Seberaya adalah sebagai berikut :

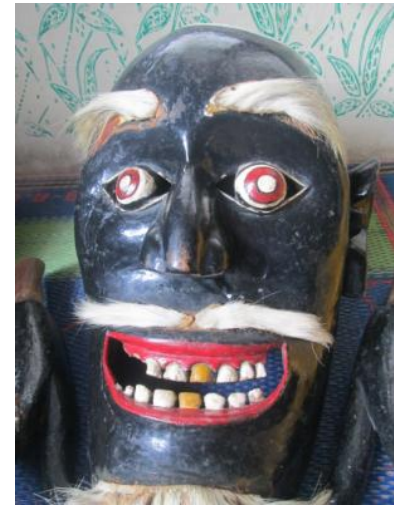

Gambar 1. Karakter Panglima (Foto Sartika $\mathrm{Br}$ Sembiring, 2016)

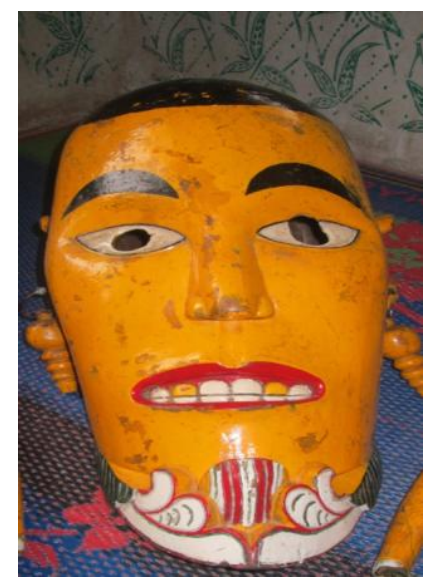

Gambar 2. Karakter Nimaisa Br Sembiring Milala (Foto Sartika Br Sembiring, 2016)

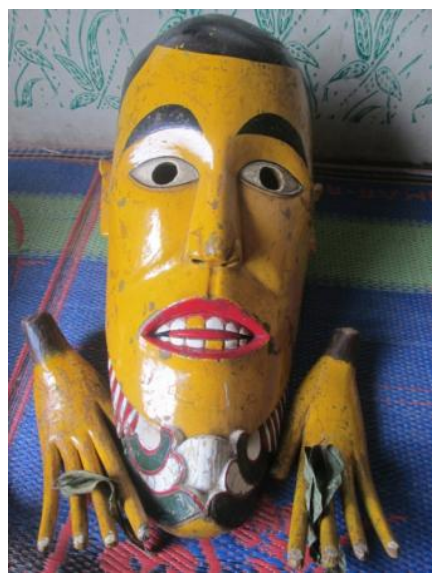

Gambar 3. Karakter Piherta Sembiring (Foto Sartika Br Sembiring, 2016)

\section{Gorga Jurnal Seni Rupa \\ Volume 07 Nomor 01 \\ p-ISSN: 2301-5942 | e-ISSN: 2580-2380}

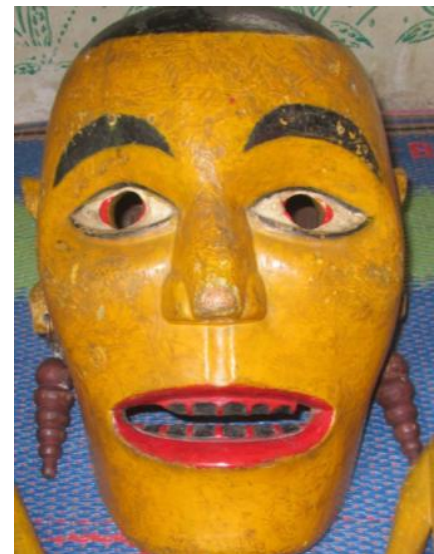

Gambar 4. Karakter Kikir Labang (Foto Sartika Br Sembiring, 2016)

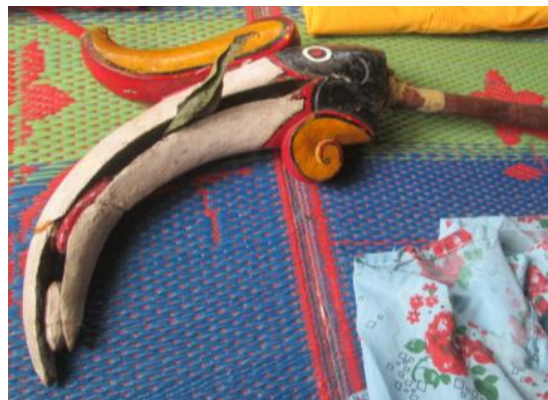

Gambar 5. Karakter Perik Gurda-gurdi (Foto Sartika Br Sembiring, 2016)

\section{KESIMPULAN DAN SARAN}

Budaya topeng tembut-tembut merupakan budaya tradisi yang berkembang dalam kehidupan masyarakat Karo khususnya Desa Seberaya. Tradisi pertunjukkan topeng ini lebih dikenal dengan sebuah tari pertunjukkan dibandingkan disebut topeng. Dalam tradisi sama lampau, tembut-tembut ini erat kaitannya dengan sebuah upacara ritual yang memiliki nilai sakral dan dipercaya oleh masyarakat Karo. Upacara ritual yang berkaitan dengan topeng ini adalah ritual pemanggilan air hujan. Ritual ini sarat akan nilai-nilai magis didalamnya. Ritual pemanggilan air hujan yang dilaksanakan memiliki prosesi yang tidak sembarangan. Prosesinya harus melewati beberapa tahap dan melibatkan anak desa setempat yaitu warga Seberaya sendiri. 


\section{Gorga Jurnal Seni Rupa \\ Volume 07 Nomor 01 \\ p-ISSN: 2301-5942 | e-ISSN: 2580-2380}

Fungsi topeng tembut-tembut dalam masyarakat Karo dari segi personal, sosial dan fisik adalah sebagai sebuah peringatan perkawinan sesama klan merga Sembiring Depari dengan Sembiring Milala. Sebagai sebuah deskripsi dari sendi-sendi kehidupan masyarakat karo. Sebagai wadah penutup bagi penari dalam sebuah pertunjukkan. Sebagai alat pemanggilan air hujan melalui iringan doa. Sebagai pesan moral nasehat agar tidak melakukan pernikahan dalam klan marga yang sama. Fenomena yang terjadi sekarang adalah pertunjukkan topeng ini di anggap sebagai pelengkap sebuah pertunjukan

Sebagai salah satu budaya tradisi, masyarakat Karo khususnya Desa Seberaya agar lebih memberikan apresiasi terhadap warisan leluhur. Hal tersebut bertujuan agar tradisi yang sarat akan nilai sakral tetap terjaga kelestariannya. Sebab tanpa perhatian dari masyarakat, maka tradisi tentang tembut-tembut bisa saja punah tergerus zaman karena dianggap sebagai pertentangan dengan agama. Masyarakat seharusnya diajak lebih memahami tradisi pertunjukkan topeng ini sebenarnya sarat akan pesan moral. Jika masyarakat tidak diberikan pemahaman yang benar, maka tradisi ini akan hilang dan generasi penerus akan kehilangan sebuah tradisi kuno yang berkaitan dengan ritual pemanggilan air hujan. Walapun pada prakteknya fenomena pertunjukkan dianggap sebagai pelengkap pertunjukkan, namun harus adanya perhatian akan makna yang tersimpan dalam topeng tembut-tembut Seberaya.

1.Supaya masyarakat Karo lebih memahami tentang fungsi topeng tembut-tembut Seberaya lebih dalam, bukan hanya melihat topeng sebagai pelengkap sebuah acara pertunjukan.

2.Pemerintah daerah memberikan perhatian terhadap budaya tradisi topeng ini agar kesenian tradisi tetap terjaga kelestariannya

3.Pemerintah daerah ikut serta memberikan informasi yang benar tentang topeng tembut-tembut sebagai salah satu budaya tradisi leluhur dalam acara-acara pemerintahan.

4.Bagi generasi muda Karo sebaiknya sejak dini belajar akan kesenian tradisi agar menimbulkan kecintaan terhadap budaya sendiri.

\section{DAFTAR RUJUKAN}

Eliade, Mircea. Sakral dan Profan. Yogjakarta: Fajar Pustaka Baru, 2002.

Feldman, Edmund Burke. Art as Image and Idea. Terj.Gustami,S.P. Yogyakarta: Institut Seni Indonesia Yogyakarta,1990.

Gazalba, S. Islam dan Kesenian. Jakarta : Pustaka Alhusna, 1989.
Holt, Claire.Melacak Jejak Pekembangan Seni di Indonesia : Masyarakat Seni Pertunjukkan Indonesia. Bandung: Arti Line Untuk MSPI (Masyarakat Seni Petunjukan Indonesia), 2000.

Koentrajaningrat. Sejarah Teori Antropologi I. Jakarta : Universitas Indonesia, 2007.

Tuner, Victor. The Ritual Proses : Structure and AntiStructure. Ithaca, New York. Cornell Paperbacks: Cornell University Press. 1977. Wawancara :

1. Dwikora Sembiring Depari (52) Generasi ke empat tembut-tembut Seberaya, Desa Seberaya.

2. Joker Barus (61) Pengrajin Topeng Desa Barus jahe. 